\title{
PENINGKATAN HASIL BELAJAR STATISTIKA MELALUI MODEL PEMBELAJARAN KOOPERATIF TIPE THINK PAIR SQUARE PADA MAHASISWA SEMESTER II PROGRAM STUDI PENDIDIKAN MATEMATIKA
}

\author{
A. Muhajir Nasir \\ Dosen Pendidikan Matematika STKIP YAPIM Maros \\ muhajirnasir@gmail.com
}

\begin{abstract}
Abstrak
Penelitian ini merupakan Penelitian Tindakan Kelas (Classroom Action Research) yang terdiri dari 2 siklus. Penelitian ini bertujuan untuk mengetahui peningkatan hasil belajar mahasiswa melalui model pembelajaran kooperatif tipe Think Pair Square. Teknik analisis data yang digunakan adalah statistik deskriptif. Subjek penelitian ini adalah mahasiswa semester II program studi Pendidikan Matematika STKIP YAPIM Maros yang berjumlah 28 orang.

Hasil penelitian menunjukkan bahwa hasil belajar mahasiswa pada siklus I diperoleh skor ratarata 71,32 dengan ketuntasan $71,43 \%$ dan pada siklus II diperoleh skor rata-rata 79,86 dengan ketuntasan 89,29\%. Peningkatan ketuntasan dari siklus I ke siklus II sebesar 17,86\%. Dengan demikian, penerapan model pembelajaran kooperatif tipe Think Pair Square dapat meningkatkan hasil belajar mahasiswa.
\end{abstract}

Kata kunci : Hasil Belajar, Model Pembelajaran Kooperatif Tipe Think Pair Square

\begin{abstract}
This research is a Classroom Action Research which consists of 2 cycles. This study aims to determine the improvement of student learning outcomes through cooperative learning model Think Pair Square type. Data analysis technique used is descriptive statistic. The subject of this research is the second semester students of Mathematics Education Program STKIP YAPIM Maros, amounting to 28 people.

The results showed that the results of student learning on the first cycle obtained an average score of 71.32 with a complete $71.43 \%$ and on the second cycle obtained an average score of 79.86 with a complete $89.29 \%$. Improved completeness from cycle I to cycle II amounted to $17.86 \%$. Thus, the application of cooperative learning model type Think Pair Square can improve student learning outcomes.
\end{abstract}

Keywords: Learning Outcomes, Cooperative Learning Model Type Think Pair Square

\section{PENDAHULUAN}

\section{A. Latar Belakang}

Pendidikan merupakan salah satu upaya dalam meningkatkan sumber daya manusia agar mampu bersaing dalam menghadapi perkembangan zaman. Tujuan pendidikan nasional dalam pasal 3 UU Nomor 20 tentang Sistem Pendidikan Nasional yang mendeskripsikan tentang pengembangan manusia yang beriman dan bertakwa kepada Tuhan yang Maha Esa, berakhlak mulia, sehat, berilmu, cakap, kreatif, mandiri, dan menjadi warga Negara yang demokratis dan bertanggung jawab. (Sani, 2014: 27).

Berdasarkan hasil observasi awal pada mahasiswa semester II program studi Pendidikan Matematika STKIP YAPIM Maros dalam proses perkuliahan, beberapa mahasiswa menganggap statistika sebagai pelajaran yang sukar dan ribet. Karenanya banyak diantara mahasiswa mengikuti pelajaran statistika tidak lebih dari rutinitas untuk mengisi daftar absensi, mencari nilai tanpa adanya kesadaran untuk menambah wawasan maupun keterampilan, mahasiswa hanya datang, duduk, mendengarkan, dan mencatat materi. Dapat disimpulkan, masalah dalam proses pembelajaran statistika berdasarkan hasil observasi tersebut: (1) mahasiswa tidak terlibat secara aktif dalam proses pembelajaran; (2) kurangnya motivasi mahasiswa dalam belajar. Kedua faktor tersebut yang menyebabkan hasil belajar mahasiswa rendah. Menurut dosen, nilai rata-rata tes hariannya adalah 66,39. Dari jumlah keseluruhan 28 orang, mahasiswa yang termasuk kategori tuntas sebanyak 13 orang atau $46,43 \%$ dan kategori tidak tuntas sebanyak 15 orang atau $53,57 \%$.

Oleh karena itu, sangatlah penting bagi dosen untuk memahami karakteristik materi dan mahasiswa 
dalam proses pembelajaran terutama berkaitan dengan pemilihan model-model pembelajaran. Menurut Uno dan Nurdin (2014: 105), kesesuaian gaya belajar membuat siswa dapat belajar sehingga tujuan pembelajaran dapat dicapai dengan optimal, maka ada berbagai model pembelajaran yang perlu diterapkan dalam kegiatan pembelajaran, tidak ada model pembelajaran yang paling tepat untuk segala situasi dan kondisi. Dalam memilih model pembelajaran yang tepat haruslah memperhatikan mahasiswa, materi, bahan ajar, fasilitas, media yang tersedia.

Menurut Huda (2012: 27), salah satu model pembelajaran yang sudah banyak diteliti lebih adalah model pembelajaran kooperatif atau cooperative learning. Pembelajaran kooperatif diyakini sebagai praktik pedagogis untuk meningkatkan proses pembelajaran, gaya berfikir tingkat-tinggi, perilaku sosial, sekaligus kepedulian terhadap mahasiswamahasiswa yang memiliki latar belakang kemampuan, penyesuaian, dan kebutuhan yang berbeda-beda. Dan menurut Johnson \& Johnson (Lie, 2002: 7) suasana belajar cooperative learning menghasilkan prestasi yang lebih tinggi, hubungan yang lebih positif, dan penyesuaian psikologis yang lebih baik daripada suasana belajar yang penuh dengan persaingan dan memisah-misahkan siswa.

Ada beberapa tipe model pembelajaran kooperatif, salah satunya adalah Think Pair Square (Berpikir-Berpasangan-Berempat). Think Pair Square yang dikembangkan oleh Spencer Kagan merupakan modifikasi dari tipe Think Pair Share (TPS) yang dikembangkan oleh Frank Lyman dari University of Maryland. Think Pair Square digunakan untuk meningkatkan kemampuan berpikir, komunikasi dan mendorong siswa untuk berbagi informasi dengan mahasiswa lain.

Dalam pembelajaran kooperatif tipe Think Pair Square, dosen membagi mahasiswa dalam kelompok heterogen (baik dari tingkat kemampuan, jenis kelamin, dan suku) yang beranggotakan empat orang. Sebagai kegiatan awal adalah Think atau tahap berpikir. Tahap selanjutnya adalah Pair atau tahap berpasangan, kemudian tahap Square dimana pasangan bergabung dengan pasangan yang lain dalam kelompoknya untuk membentuk kelompok berempat (Lie, 2002: 56). Sehingga diharapkan dapat memotivasi mahasiswa agar berperan aktif dalam pembelajaran di kelas dan dapat meningkatkan hasil belajar mahasiswa.

Berdasarkan uraian di atas, maka dilaksanakan penelitian dengan judul “ Peningkatan Hasil Belajar Statistika Melalui Model Pembelajaran Kooperatif
Tipe Think Pair Square pada Mahasiswa Semester II Program Studi Pendidikan Matematika”.

\section{B. Rumusan Masalah}

Berdasarkan latar belakang di atas, maka rumusan masalah dalam penelitian ini sebagai berikut:

1. Bagaimanakah aktivitas mahasiswa dan aktivitas dosen dalam pengelolaan pembelajaran melalui model pembelajaran kooperatif tipe Think Pair Square pada mahasiswa semester II program studi pendidikan matematika STKIP YAPIM Maros?

2. Bagaimanakah peningkatan hasil belajar statistika melalui model pembelajaran kooperatif tipe Think Pair Square pada mahasiswa semester II program studi pendidikan matematika STKIP YAPIM Maros?

\section{METODOLOGI PENELITIAN}

\section{A. Jenis Penelitian}

Penelitian ini merupakan Penelitian Tindakan Kelas (Classroom Action Research). Tindakan yang diberikan adalah penggunaan model pembelajaran kooperatif tipe Think Pair Square dengan tahapantahapan perencanaan, pelaksanaan/tindakan, pengamatan/observasi, dan refleksi

\section{B. Subjek Penelitian}

Subjek dalam penelitian ini adalah mahasiswa semester II program studi pendidikan matematika STKIP YAPIM Maros dengan jumlah mahasiswa 28 orang dengan komposisi 11 perempuan dan 17 lakilaki.

\section{Variabel dan Desain Penelitian \\ 1. Variabel Penelitian}

Variabel penelitian tindakan kelas ini terdiri dari variabel bebas dan variabel terikat. Adapun variabel bebas adalah model pembelajaran kooperatif tipe Think Pair Square dan Variabel terikat adalah hasil belajar statistika mahasiswa semester II program studi pendidikan matematika STKIP YAPIM Maros.

\section{Desain Penelitian}

Proses penelitian tindakan kelas merupakan sebuah siklus yang terdiri dari aspek perencanaan, pelaksanaan/tindakan, pengamatan/ observasi dan refleksi.

a. Perencanaan adalah penyusunan tindakantindakan yang akan dikembangkan dalam pembelajaran.

b. Pelaksanaan/Tindakan adalah praktek pembelajaran nyata berdasarkan rencana 
tindakan yang telah disusun bersama peneliti dan dosen.

c. Pengamatan/Observasi adalah mengamati seluruh proses tindakan sampai pada saat selesai tindakan.

d. Refleksi adalah mengkaji dan merenungkan kembali informasi-informasi awal berkenaan dengan adanya ketidaksesuaian dengan praktek pembelajaran.

\section{Teknik Pengumpulan Data}

Adapun teknik pengumpulan data yang digunakan dalam penelitian tindakan kelas ini adalah :

1. Data tentang hasil belajar mahasiswa dengan menggunakan tes hasil belajar metematika yang diambil dari setiap siklus, yang dibuat oleh peneliti bekerja sama dengan dosen yang bersangkutan.

2. Data tentang kondisi mahasiswa dan situasi perkuliahan pada saat dilakukan tindakan diambil dengan menggunakan lembar observasi.

\section{E. Teknik Analisis Data}

Data yang telah terkumpul dianalisis dengan menggunakan teknik analisis kuantitatif dan analisis kualitatif. Data yang diperoleh dari observasi dianalisis secara kualitatif, sedangkan data mengenai hasil belajar mahasiswa semester II program studi pendidikan matematika STKIP YAPIM Maros dianalisis secara kualitatif dengan menggunakan statistik deskriptif untuk mendeskripsikan karakteristik dari subjek penelitian. Statistik deskriptif yang dimaksudkan untuk mendeskripsikan secara verbal tentang peningkatan hasil belajar mahasiswa setelah diadakannya test.

\section{F. Indikator Keberhasilan}

Kriteria keberhasilan dalam penelitian ini yaitu apabila terjadi peningkatan hasil belajar statistika mahasiswa semester II program studi pendidikan matematika STKIP YAPIM Maros melalui model pembelajaran kooperatif tipe Think Pair Square dan menunjukkan ketuntasan belajar secara klasikal yaitu $\geq 85 \%$. Adapun, mahasiswa secara invidual dikatakan tuntas belajar jika mahasiswa memenuhi kriteria ketuntasan minimal (KKM) yaitu 70. Dapat dilihat pada Tabel berikut.

Tabel 1 Pemetaan Tingkat Ketuntasan Hasil Belajar Statistika

\begin{tabular}{cc}
\hline Skor & Kategori \\
\hline $0-69$ & Tidak Tuntas \\
\hline $70-100$ & Tuntas \\
\hline
\end{tabular}

\section{HASIL DAN PEMBAHASAN}

\section{A. Hasil Penelitian}

\section{Siklus I}

Hasil belajar mahasiswa setelah mengikut proses pembelajaran melalui model pembelajaran koopertif tipe Think Pair Square pada mahasiswa semester II program studi pendidikan matematika STKIP YAPIM Maros dapat dilihat pada Tabel 2 berikut yang diperoleh dari hasil analisis statistik dengan menggunakan aplikasi SPSS versi 16.0 yaitu :

Tabel 2 Deskripsi Nilai Hasil Belajar Statistika Mahasiswa pada Tes Evaluasi Siklus I

\begin{tabular}{lc}
\hline \multicolumn{1}{c}{ Statistik } & Nilai Statistik \\
\hline Subjek Penelitian & 28 \\
\hline Skor Ideal & 100 \\
\hline Skor Tertinggi & 97 \\
\hline Skor Terendah & 43 \\
\hline Rentang Skor & 54 \\
\hline Skor Rata-rata & 71,32 \\
\hline Median & 73 \\
\hline Modus & 76 \\
\hline Variansi & 174,152 \\
\hline Standar Deviasi & 13,197 \\
\hline
\end{tabular}

Berdasarkan Tabel 2, hasil belajar mahasiswa pada siklus I melalui model pembelajaran kooperatif tipe Think Pair Square pada mahasiswa semester II program studi pendidikan matematika STKIP YAPIM Maros dengan subjek penelitian 28 orang. Diperoleh skor tertinggi adalah 97, skor terendah adalah 43, rentang skor adalah 54 dan skor rata-rata yang diperoleh mahasiswa pada siklus I adalah 71,32. Selain itu diperoleh median yaitu 73, modus yaitu 76 serta diperoleh standar deviasi sebesar 13,197 dan variansi sebesar 174,152.

Selain itu, persentase ketuntasan hasil belajar mahasiswa pada siklus I dapat dilihat pada Tabel 3 berikut:

Tabel 3 Ketuntasan Hasil Belajar Mahasiswa pada Siklus I

\begin{tabular}{|c|c|c|c|}
\hline Nilai & Kategori & $f$ & $(\%)$ \\
\hline $0-69$ & Tidak Tuntas & 8 & 28,57 \\
\hline $70-100$ & Tuntas & 20 & 71,43 \\
\hline \multicolumn{2}{|c|}{ Jumlah } & 28 & 100 \\
\hline
\end{tabular}


Tabel 3 menunjukkan bahwa persentase hasil ketuntasan belajar pada mahasiswa semester II program studi pendidikan matematika sebesar 71,43\% atau sejumlah 20 orang sedangkan persentase ketidaktuntasan sebesar $28,57 \%$ atau sejumlah 8 orang dari 28 mahasiswa.

\section{Siklus II}

Hasil belajar mahasiswa diperoleh dari tes evaluasi yang diberikan pada akhir siklus II. Tes tersebut berupa soal essay yang terdiri atas 5 nomor. Hasil belajar setelah mengikuti proses pembelajaran dengan model pembelajaran kooperatif tipe Think Pair Square dapat dilihat pada Tabel 4 berikut yang diperoleh dari hasil analisis statistik dengan menggunakan aplikasi SPSS versi 16.0 yaitu:

Tabel 4 Deskripsi Nilai Hasil Belajar Statistika Mahasiswa pada Tes Evaluasi Siklus II

\begin{tabular}{lc}
\hline \multicolumn{1}{c}{ Statistik } & Nilai Statistik \\
\hline Subjek Penelitian & 28 \\
\hline Skor Ideal & 100 \\
\hline Skor Tertinggi & 100 \\
\hline Skor Terendah & 56 \\
\hline Rentang Skor & 44 \\
\hline Skor Rata-rata & 79,86 \\
\hline Median & 81 \\
\hline Modus & 83 \\
\hline Variansi & 129,386 \\
\hline Standar Deviasi & 11,375 \\
\hline
\end{tabular}

Berdasarkan Tabel diatas, hasil belajar mahasiswa pada siklus II melalui model pembelajaran kooperatif tipe Think Pair Square pada pada mahasiswa semester II program studi pendidikan matematika dengan subjek penelitian 28 orang. Diperoleh skor tertinggi adalah 100, skor terendah adalah 56, rentang skor adalah 44 dan skor rata-rata yang diperoleh mahasiswa pada siklus I adalah 79,86. Selain itu diperoleh median yaitu 81 , modus yaitu 83 serta diperoleh standar deviasi sebesar 11,375 dan variansi sebesar 129,386.

Persentase ketuntasan belajar mahasiswa pada siklus II dapat dilihat pada Tabel 5 berikut:

Tabel 5 Ketuntasan Hasil Belajar Mahasiswa pada Siklus II

\begin{tabular}{clcc}
\hline Nilai & Kategori & $\boldsymbol{f}$ & $(\boldsymbol{\%})$ \\
\hline $0-69$ & Tidak Tuntas & 3 & 10,71 \\
\hline $70-100$ & Tuntas & 25 & 89,29 \\
\hline \multicolumn{2}{c}{ Jumlah } & $\mathbf{2 8}$ & $\mathbf{1 0 0}$ \\
\hline
\end{tabular}

Tabel 5 menunjukkan bahwa persentase hasil ketuntasan belajar pada mahasiswa semester II program studi pendidikan matematika sebesar 89,29\% atau sejumlah 25 orang sedangkan persentase ketidaktuntasan sebesar $10,71 \%$ atau sejumlah 3 orang dari 28 mahasiswa. Karena persentase pada siklus II telah mencapai target tuntas secara klasikal sehingga tidak perlu dilanjutkan ke siklus berikutnya.

\section{B. Pembahasan}

Berdasarkan analisis data, pada siklus I diperoleh skor rata-rata mahasiswa yaitu 71,32 dengan persentase ketuntasan yaitu $71,43 \%$ atau sejumlah 20 orang dan persentase ketidaktuntasan yaitu $28,57 \%$ atau sejumlah 8 orang dari 28 jumlah mahasiswa.

Pada pelakasanaan siklus I, ditemukan beberapa kendala yaitu kurangnya interaksi antar mahasiswa dalam kelompoknya yaitu mahasiswa tidak saling bekerja sama karena merasa tidak cocok dengan anggota kelompoknya, begitupun keaktifan mahasiswa dalam mengerjakan tugas masih kurang, adapula hanya bercerita diluar materi pembelajaran dengan teman kelompoknya akibatnya anggota lain merasa terganggu.

Berdasarkan hasil refleksi pelaksanaan siklus I tersebut, dalam upaya meningkatkan hasil belajar mahasiswa maka dilakukan perbaikan dalam pelaksanaan siklus II. Tindakan yang dilakukan yaitu dosen atau peneliti mengubah anggota kelompok agar mahasiswa dapat lebih banyak berinteraksi dengan mahasiswa yang lainnya sehingga mahasiswa yang tergolong memiliki kemampuan tinggi dapat membantu temannya yang memiliki kemampuan rendah dalam menyelesaikan soal yang diberikan, melakukan pendekatan kepada mahasiswa yang tidak memusatkan perhatiannya terhadap pembelajaran, meningkatkan pemberian bimbingan yang dapat dilihat pada lembar observasi dosen dalam pengelolaan pembelajaran. Disamping itu memberikan penghargaan (pujian) agar mahasiswa lebih aktif dan semangat dalam pembelajaran dan tidak lagi saling menganggu.

Pada pelaksanaan siklus II terlihat bahwa tindakan yang dilaksanakan, secara umum memberikan hasil sesuai yang diharapkan. Berdasarkan hasil yang diperoleh pada siklus II terjadi peningkatan hasil belajar mahasiswa yaitu diperoleh skor rata-rata mahasiswa menjadi 79,86 dengan persentase ketuntasan adalah $89,29 \%$ atau sejumlah 25 orang dan persentase ketidaktuntasan adalah $10,71 \%$ atau sejumlah 3 orang dari 28 jumlah mahasiswa. Peningkatan ketuntasan dari siklus I ke 
siklus II sebesar 17,86\%. Mahasiswa yang tidak tuntas diberikan remedial dengan cara pemberian tugas, terlihat 3 mahasiswa mengerjakan tugasnya dengan baik. Setelah pelaksanaan remedial, mahasiswa tersebut dikatakan tuntas karena sudah memenuhi KKM yaitu 70 .

Dari hasil ketuntasan yang diperoleh mahasiswa pada siklus II menunjukkan hasil belajar mahasiswa dinyatakan tuntas secara klasikal karena mahasiswa yang tuntas belajar telah melebihi $85 \%$ sehingga tidak perlu dilanjutkan ke siklus berikutnya.

Dalam proses pembelajaran siklus II, perhatian mahasiswa pada saat dosen menjelaskan semakin bertambah dan terlihat interaksi antar mahasiswa yaitu semakin terjalinnya kerjasama dalam kelompoknya lebih banyak berdiskusi tentang materi yang diajarkan, baik pada saat berpasangan, dalam kelompok berempat, maupun diskusi kelas, sehingga mahasiswa lebih mudah memahami materi dan setiap soal yang diberikan sehingga hasil belajar statistika pada mahasiswa semester II program studi pendidikan matematika meningkat. Dengan demikian, penerapan model pembelajaran kooperatif tipe Think Pair Square dapat meningkatkan hasil belajar mahasiswa yang merupakan keberhasilan dalam proses pembelajaran.

\section{PENUTUP}

\section{A. Kesimpulan}

Berdasarkan hasil penelitian yang berlangsung selama dua siklus disimpulkan bahwa penerapan model pembelajaran kooperatif tipe Think Pair Square dapat meningkatkan hasil belajar statistika pada pada mahasiswa semester II program studi pendidikan matematika dibuktikan dengan adanya peningkatan persentase ketuntasan yaitu pada siklus I diperoleh persentase ketuntasan $71,43 \%$ atau sejumlah 20 orang menjadi $89,29 \%$ pada siklus II atau sejumlah 25 orang dari 28 jumlah mahasiswa. Persentase ketuntasan meningkat sebesar $17,86 \%$.

\section{B. Saran}

Pada hasil penelitian ini, adapun saran dalam upaya meningkatkan mutu pendidikan antara lain :

1. Model pembelajaran kooperatif tipe Think Pair Square dapat dijadikan sebagai salah satu alternatif dalam melaksanakan pembelajaran statistika.

2. Penerapan model pembelajaran kooperatif tipe Think Pair Square sangat dibutuhkan perencanaan yang baik agar dapat berjalan secara efektif.
3. Diharapkan kepada dosen bidang studi statistika yang lain agar mampu mengembangkan dan menerapkan pembelajaran kooperatif tipe Think Pair Square dalam upaya peningkatan hasil belajar mahasiswa.

\section{DAFTAR PUSTAKA}

[1] Annurrahman. 2009. Belajar dan Pembelajaran. Bandung : Alfabeta.

[2] Arikunto, Suharsimi dkk. 2014. Penelitian Tindakan kelas. Jakarta : PT Bumi Aksara.

[3] Hamdayama, Jumanta. 2015. Model dan Metode Pemebelajaran Kreatif dan Berkarakter. Bogor : Ghalia Indonesia.

[4] Hartuti, Evi Rine dkk. 2007. Ensiklopedi Matematika. Yogyakarta : Empat Pilar Pendidikan.

[5] Huda, Miftahul. 2011. Cooperative Learning Metode, Teknik, Struktural dan Model Penerapan. Yogyakarta : Penerbit Pustaka Pelajar.

[6] Jumiati. 2016. "Peningkatan Hasil Belajar Matematika Konsep Segi Empat melalui Model Pembelajaran Kooperatif Tipe Think Pair Share (TPS) Pada Siswa Kelas VIIB MTs DDI Soreang Kec.Lau Kab.Maros”. Skripsi. STKIP YAPIM Maros.

[7] Kunandar. 2014. Penilaian Autententik (Penilaian hasil belajar peserta didik berdasarkan kurikulum 2013). Jakarta : PT Rajagrafindo Persada.

[8] Lie, Anita. 2002. Cooperative Learning: Mempraktikkan Cooperative Learning di Ruang-Ruang Kelas. Jakarta : Grasindo.

[9] Mulyasa, E. 2007. Kurikulum Bebasis Kompetensi : Konsep, Karakteristik, dan Implementasi. Bandung : Remaja Rosdakarya.

[10] Nasir, A. Muhajir. 2011. "Pengembangan Perangkat Pembelajaran Model Pengajaran Langsung yang Melibatkan Media Animasi”. Skripsi. Universitas Negeri Makassar.

[11] Prawira, Purwa Atmaja. 2012. Psikologi Pendidikan dalam Perspektif Baru. Jogjakarta : Ar-ruzz Media.

[12] Rahmawati. 2013. "Pola Interaksi Siswa Berdasarkan Gaya Kognitif Dalam Pembelajaran Matematika Kooperatif tipe Think Pair Square (Studi pada siswa kelas VIII SMP NEGERI 2 MAROS". Tesis. Universitas Negeri Makassar.

[13] Risnawati. 2014. "Meningkatkan Hasil Belajar Matematika Melalui Penerapan Model 
Pembelajaran Kooperatif Tipe Numbered Heads Together (NHT) Pada Murid Kelas V SD Negeri 45 Pappaka Kabupaten Maros". Skripsi. FKIP. Universitas Muhammadiyah Makassar.

[14] Ruhimat, Toto dkk. 2013. Kurikulum dan Pembelajaran. Depok : PT Raja Grafindo Persada.

[15] Rusman. 2010. Model-Model Pembelajaran: Mengembangkan Profesionalisme Guru. Jakarta: PT. Raja Grafindo Persada.

[16] Sani, Ridwan Abdullah. 2014. Pembelajaran Saintifik untuk Implementasi Kurikulum 2013. Jakarta : PT Bumi Aksara.

[17] Suriati, Lili. 2012. "Penerapan Model Pembelajaran Kooperatif Tipe Think Pair Square Untuk Meningkatkan Hasil Belajar Matematika Peserta didik Kelas IV SDN 003 Sotol Kec. Langgam Kab. Pelalawan”. Jurnal
Ilmu Pendidikan. Online. (http://repository.unri.ac.id/jspui/bitstream/123 456789/2299/1/Jurnal\%20Lili.pdf). Diakses 17 November 2016 Pukul 21:53 WITA.

[18] Trianto. 2013. Model Pembelajaran Terpadu : Konsep, Strategi dan Implementasinya dalam Kurikulum Tingkat Satuan Pendidikan (KTSP). Jakarta : Bumi Aksara.

[19] Uno, Hamzah B dan Nurdin Mohammad. 2014. Belajar dengan Pendekatan Pembelajaran Aktif Inovatif Lingkungan Kreatif Efektif Menyenangkan. Jakarta : Bumi Aksara.

[20] Wisudawati, Asih Widi dan Eka Sulistyowati. 2014. Metodologi Pembelajaran IPA. Jakarta : Bumi Aksara.

[21] Yamin, Moh. 2015. Teori dan Model Pembelajaran. Jatim: Madani (Kelompok Intrans Publishing). 